\title{
MALDITOS NOS TRÓPICOS
}

Em matéria de literatura, a linhagem "maldita" brasileira ainda resta pouco explorada pela crítica. De Gregório de Matos a Qorpo-Santo, de Gilka Machado a Hilda Hilst, de Febrônio Índio do Brasil a João Antônio, ou de Dalton Trevisan a Glauco Mattoso, para citar apenas alguns nomes que figuram neste dossiê, não são poucos os escritores do país que poderiam ser reconhecidos sob tal rubrica, dada sua forte identidade literária com o sentido que a expressão ganhou na França a partir do século xix.

Como se sabe, para além dos poetas elencados por Verlaine em seu famoso artigo de 1883 para a revista Lutèce, que destacava as figuras de Corbière, Rimbaud e Mallarmé, a ideia do "escritor maldito" já era corrente na sensibilidade romântica, passando por Alfred de Vigny ou Gérard de Nerval, para culminar no criador das Flores do mal. Além disso, a expressão também serviu a uma série de autores vanguardistas que se proclamaram herdeiros não só dos poetas oitocentistas, mas igualmente de uma galeria de "malditos" avant la lettre, que vai de François Villon a Sade.

Cabe dizer que, desde meados dos Oitocentos, vários desses franceses foram traduzidos, debatidos, encenados e, sobretudo, admirados por artistas e intelectuais locais que, não raro, formaram grupos de leitores entusiastas de obras proscritas pela moralidade corrente e por vezes até mesmo proibidas. Os exemplos são abundantes. Para citar só alguns, vale lembrar que Cruz e Sousa foi grande leitor de Baudelaire, que Murilo Mendes dedicou mais de um poema ao soturno conde de Lautréamont, que Artaud e Genet foram influências decisivas no teatro nacional da segunda metade do século $\mathrm{xx}$, e que o "divino marquês" foi objeto de diversas homenagens na poesia transgressiva de Roberto Piva.

O presente dossiê se propõe a interrogar alguns dos traços que particularizam essa linhagem na nossa literatura, de seus primórdios barrocos até a atualidade. De forma geral, ele se compõe de um conjunto de reflexões apresentadas no colóquio Malditos nos trópicos, que, promovido por uma parceria entre a pós-graduação em Literatura Brasileira da usp e o Centre de Recherches en Littérature et Poétique Comparées da Universidade Paris Ouest Nanterre La Défense, teve uma edição no Brasil e outra na França ao longo do ano de 2013. 
A rigor, mais que a recepção dos malditos das letras francesas no país, os textos críticos deste conjunto buscam refletir sobre as ressonâncias entre as duas literaturas. Ou seja, para além da influência direta, interessa reconhecer pontos de contato entre ambas as escritas, voltando particular atenção aos autores que exploraram manifestações do excesso, da transgressão e do erotismo. Trata-se de um diálogo entre pesquisadores europeus e brasileiros, tendo em vista uma reflexão sobre as principais dimensões simbólicas e formais que constituem as chamadas obras "malditas", seja no interior do corpus já canônico da França, seja na identificação desses mesmos traços na paisagem literária do Brasil. Trata-se, ainda, de uma oportunidade para indagar a existência de um "tropismo tropical" nos escritores do além-mar. Assim, mais que um eventual exercício de literatura comparada, o que se propõe aqui é sobretudo a exploração de um paradigma que permite tanto destacar aspectos da literatura brasileira ainda pouco trabalhados entre nós quanto abordar os textos franceses sob uma nova perspectiva.

Além das comunicações do colóquio, este número da revista Teresa traz também três resenhas de títulos publicados em 2014 que tangenciam o tema do dossiê: Renato Adura Martins propõe uma fértil comparação entre os missivistas do volume Mário de Andrade e Sérgio Buarque de Holanda: correspondência, compilado por Pedro Meira Monteiro; Luisa Destri analisa a fundo as entrevistas de Hilda Hilst em Fico besta quando me entendem, organizado por Cristiano Diniz; e Adriano Schwartz ressalta a singularidade da intervenção crítica de João Camillo Penna nos ensaios reunidos em Escritos da sobrevivência.

Destaquem-se ainda outras duas contribuições de peso, que conferem particular densidade a esta edição. De um lado, o ensaio fotográfico assinado por Antonio Saggese que, a seu modo, insinua uma possível tradução tropical do estado de espírito saturnino dos escritores europeus aqui em questão. De outro, a entrevista de Berta Waldman, autora de trabalhos pioneiros sobre Dalton Trevisan e uma das mais finas intérpretes de outros "malditos" da nossa literatura, como Nelson Rodrigues ou Samuel Rawet. Às vésperas da publicação de seu novo livro, intitulado Ensaios sobre a obra de Dalton Trevisan, a professora e pesquisadora discorreu sobre suas afinidades eletivas nas letras brasileiras, e seu inesgotável interesse pela "dialética da cafajestagem".

Camille Dumoulié

Eliane Robert Moraes 